\title{
Interstitial Lung Disease in Rheumatoid Arthritis Remains a Challenge for Clinicians
}

\author{
Elisabeth Bendstrup ${ }^{1, * \mathbb{C}}$, Janne Møller ${ }^{1}$, Sissel Kronborg-White ${ }^{1}$, Thomas Skovhus Prior ${ }^{1} \mathbb{C}$ \\ and Charlotte Hyldgaard ${ }^{2}$ \\ 1 Center for Rare Lung Diseases, Department of Respiratory Diseases and Allergy, Aarhus University \\ Hospital, Palle Juul-Jensens Boulevard 99, 8200 Aarhus, Denmark; jannmoel@rm.dk (J.M.); \\ siskro@rm.dk (S.K.-W.); Thomas.Prior@auh.rm.dk (T.S.P.) \\ 2 Diagnostic Centre, University Research Clinic for Innovative Patient Pathways, Silkeborg Regional Hospital, \\ Falkevej 1-3, 8600 Silkeborg, Denmark; charhyld@rm.dk \\ * Correspondence: kabend@rm.dk; Tel.: +45-7846-2201
}

Received: 27 August 2019; Accepted: 20 November 2019; Published: 21 November 2019

\begin{abstract}
Interstitial lung disease (ILD) is a serious complication of rheumatoid arthritis (RA) contributing to significantly increased morbidity and mortality. Other respiratory complications, such as chronic obstructive pulmonary disease and bronchiectasis, are frequent in RA. Infections and drug toxicity are important differential diagnoses and should be considered in the diagnostic work-up of patients with RA presenting with respiratory symptoms. This review provides an overview of the epidemiology and pathogenesis of RA-ILD, the radiological and histopathological characteristics of the disease as well as the current and future treatment options. Currently, there is no available evidence-based therapy for RA-ILD, and immunosuppressants are the mainstay of therapy. Ongoing studies are exploring the role of antifibrotic therapy in patients with progressive fibrotic ILD, which may lead to a new treatment approach for subgroups of patients with RA-ILD.
\end{abstract}

Keywords: rheumatoid arthritis; interstitial lung disease; usual interstitial pneumonia; non-specific interstitial pneumonia; organizing pneumonia; therapy

\section{Introduction}

Rheumatoid arthritis (RA) is a systemic inflammatory disease primarily affecting synovial joints with possible involvement of other organs. It is most often diagnosed in the fourth and fifth decades of life, and women are affected three times as often as men. The lung is a common site of extra-articular disease. Rheumatoid arthritis-associated interstitial lung disease (RA-ILD) is one of the most feared manifestations and causes serious morbidity and increased mortality [1-3]. Rheumatoid arthritis is the most common of the connective tissue diseases, and a substantial number of patients with RA will consult general practitioners, rheumatologists, and pulmonologists with respiratory symptoms which, in some cases, may be caused by ILD. Evaluation of respiratory symptoms in patients with RA is challenging because of the many potential causes to be considered including ILD, chronic obstructive pulmonary disease (COPD), bronchiectasis, respiratory infections following immunosuppressive therapies, drug-induced pulmonary toxicity, and ischemic heart disease [4].

The aim of the present review was to provide an overview of epidemiology, diagnostics, treatment, and prognosis in RA-ILD. 


\section{Epidemiology and Risk Factors}

Clinically significant RA-ILD is identified in $2 \%$ to $10 \%$ of patients with RA, but reported estimates vary due to the heterogeneity of RA, genetic susceptibility, and differences in disease definition and diagnostic methods [3,5-8].

The lifetime risk of developing ILD in patients with RA is reported to be $6 \%-15 \%$ [9-11]. Interstitial lung disease may precede the development of articular manifestations. Hyldgaard et al. [5] found that $14 \%$ of patients with RA-ILD had been diagnosed with ILD one to five years before the RA diagnosis [3]. The risk of developing ILD increases with prolonged duration of RA. Several risk factors for development of ILD in patients with RA have been identified. The most consistently reported risk factors include older age and male gender [5,11,12], cigarette smoking [12,13], positive anti-cyclic citrullinated peptide antibodies (anti-CCP) or IgM rheumatoid factor $[5,12,14]$, and, in some studies, RA disease activity $[5,11]$. Smoking is the only preventable risk factor.

\section{Pathogenesis}

A combination of genetic predisposition and environmental factors seem to be involved in RA-ILD. Restrepo et al. [5] found an increased susceptibility to RA-ILD in smokers with human leukocyte antigen (HLA) DRB1 shared epitopes. This HLA genotype has previously been shown to increase the risk of RA and anti-CCP, especially in smokers $[5,15]$. Other HLA variants are also associated with RA-ILD [16-18].

These HLA variants have a higher binding affinity to citrullinated proteins and an increased tendency to present citrullinated peptides to immune cells. The initial event may take place in mucosal sites [19]. Citrullination is the conversion of the amino acid arginine into the amino acid citrulline. Anti-citrullinated protein antibodies (ACPAs) are synthesized in genetically predisposed individuals during inflammation; these antibodies are found in the majority of patients with RA [20]. The ACPAs are directed against peptides and proteins that have been citrullinated, and smoking induces protein citrullination in the lungs [21]. Thus, the lungs may be the site of the initial immune dysregulation, leading to the development of RA, at least in smokers [19,22,23]. Paulin et al. [24] hypothesized that two potential pathways may explain different patterns of ILD in patients with RA:

(1) The immune response in RA primarily takes place in the synovial tissue in the joints. In some patients, citrullinated peptides may also be produced in the lungs, possibly causing an immune response. Fibroblasts in the lungs are activated and differentiate into myofibroblasts that produce fibrosis. Due to the inflammatory nature of the initial changes, interstitial lung inflammation develops. This process may explain the formation of a predominantly inflammatory disease pattern such as non-specific interstitial pneumonia (NSIP);

(2) In patients with fibrotic ILD, ageing alveolar epithelial cells gain the ability to secrete substances that promote the formation of tissue fibrosis in patients with a genetic susceptibility to RA. The ACPAs synthesized due to the citrullination in the lungs may also affect other tissue showing citrullinated peptides, e.g., synovium. This process may explain the formation of a predominantly fibrotic disease pattern such as usual interstitial pneumonia (UIP) [24,25].

Genetic factors may also play a role in the development of RA-ILD. Juge et al. [26] performed a whole exome sequencing study on patients with RA-ILD and found mutations in familial pulmonary fibrosis-risk genes (TERT, RTEL1, PARN, and SFTPC). An association between the MUC5B gene variant, a protein coding gene associated with the lubricating and viscoelastic properties of lung mucus, and RA-ILD has been found, similar to findings in idiopathic pulmonary fibrosis and chronic hypersensitivity pneumonitis [8,27]. 


\section{Symptoms and Clinical Features}

\subsection{Symptoms}

Symptoms of ILD are indistinguishable from a number of more common lung diseases and include exertional dyspnea, cough, chest pain, and fatigue [28-31].

A clinical examination may show digital clubbing and/or Velcro-crackles on lung auscultation in patients with fibrotic ILD. Clubbing has been reported in up to $15 \%$ of patients with RA-ILD [32]. Bilateral basal crackles have been reported in $72 \%-100 \%$ of patients with RA-ILD. Crackles were also present in patients with RA without ILD but to a smaller extent $[23,32]$. The variability of the clinical appearance is most likely due to the heterogeneity of the disease and variability in high-resolution computed tomography (HRCT) patterns.

\subsection{Imaging}

Chest X-ray is an insensitive method to detect ILD in patients with RA. Up to $64 \%$ of patients with ILD on HRCT will not have evident interstitial changes on a chest X-ray $[29,33]$. Therefore, HRCT is a mandatory part of the diagnostic work up if ILD is suspected.

The presence of lung abnormalities has been reported in $47 \%-67 \%$ of unselected patients with RA examined by HRCT [31,33-37]; ILD, respiratory disease, and bronchiectasis are common findings.

Radiological findings in RA-ILD include ground glass-opacities, reticulation, consolidation, honeycombing, and nodules similar to other ILD subtypes $[30,33,38,39]$. The most common HRCT patterns in RA-ILD are UIP and NSIP, while organizing pneumonia (OP) and bronchiolitis are less common (Figure 1) (Table 1) [8,14,38-47]. Studies show a fairly good correlation between HRCT and histopathological findings with the least concordance in the diagnosis of UIP and NSIP $[39,42,46]$.

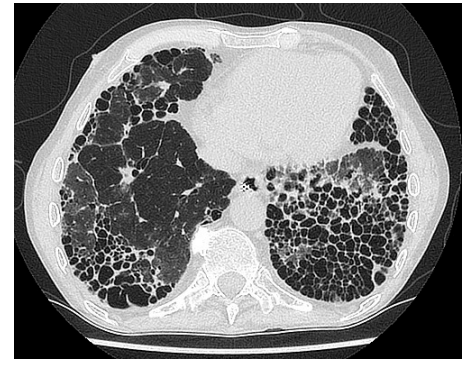

(a)

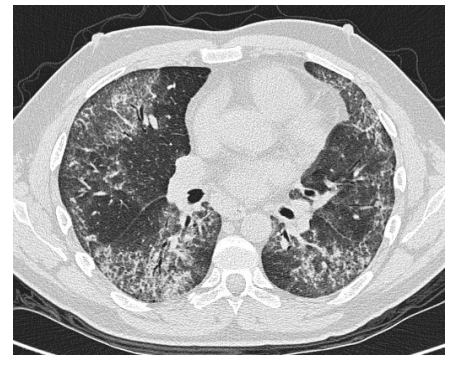

(b)

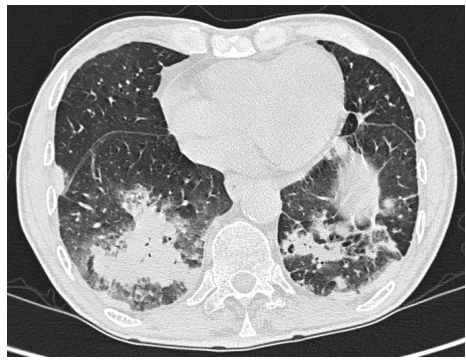

(c)

Figure 1. HRCT images showing (a) rheumatoid arthritis-associated usual interstitial pneumonia (RA-UIP), (b) rheumatoid arthritis-associated non-specific interstitial pneumonia (RA-NSIP), and (c) rheumatoid arthritis-associated organizing pneumonia (RA-OP). 
Table 1. High-resolution computed tomography (HRCT) patterns in patients with rheumatoid arthritis-associated interstitial lung disease (RA-ILD).

\begin{tabular}{|c|c|c|c|c|c|c|c|c|c|}
\hline \multirow{2}{*}{ Studies } & \multirow{2}{*}{$\begin{array}{l}\text { Total Number of Subjects } \\
\text { with ILD }(n=1138)\end{array}$} & \multirow{2}{*}{$\mathrm{UIP}(n)$} & \multirow{2}{*}{ Non-UIP $(n)$} & \multicolumn{5}{|c|}{ Subtypes of Non-UIP $(n)$} & \multirow{2}{*}{$\begin{array}{l}\text { HRCT No } \\
\text { Performed }\end{array}$} \\
\hline & & & & $\operatorname{NSIP}(n)$ & Bronchiolitis $(n)$ & OP $(n)$ & DAD (n) & Other $(n)$ & \\
\hline $\begin{array}{c}\text { Tanaka et al. } \\
\text { Radiology 2004 [39] }\end{array}$ & 63 & 26 & 37 & 19 & 11 & 5 & - & 2 & - \\
\hline Mori et al. Journal of Rheumatology 2008 [41] & 25 & 2 & 23 & 11 & 10 & 2 & - & & - \\
\hline Kim et al. European Respiratory Journal 2010 [42] & 84 & 20 & 64 & 19 & - & - & - & 45 & - \\
\hline Tsuchiya et al. European Respiratory Journal 2011 [45] & 102 & 57 & 26 & 16 & - & 5 & 5 & - & 19 \\
\hline Kelly et al. Annals of Rheumatology Dis 2014 [48] & 231 & 150 & 81 & 55 & - & 12 & - & 14 & - \\
\hline Assayag et al. Radiology 2014 [46] & 69 & $38^{*}$ & $31 * *$ & - & - & - & - & - & - \\
\hline Yunt et al. Respiratory Medicine 2017 [43] & 195 & 123 & 72 & 35 & 28 & 4 & - & 5 & - \\
\hline Zhang et al. Annals of Rheumatic Diseases 2017 [49] & 237 & 44 & 193 & 137 & - & - & - & 56 & - \\
\hline Juge et al. New England Journal of Medicine 2018 [8] & 620 & $207^{*}$ & $298^{* *}$ & - & - & - & - & - & - \\
\hline Zamora-Legoff et al. Rheumatology 2017 [40] & 181 & 98 & 77 & 73 & - & 4 & - & - & - \\
\hline Morisset et al. Respiratory Medicine 2017 [47] & 309 & $125^{*}$ & $184^{* *}$ & - & - & - & - & - & - \\
\hline Nurmi et al. Respiratory Medicine 2018 [44] & 60 & 36 & 24 & 8 & - & 7 & 1 & 8 & - \\
\hline$\%$ of total & $100 \%$ & $43 \%$ & $51 \%$ & $17 \%$ & $2 \%$ & $2 \%$ & $0 \%$ & $6 \%$ & $1 \%$ \\
\hline
\end{tabular}

* Both definite and possible UIP. ** Inconsistent with UIP. UIP: usual interstitial pneumonia, NSIP: non-specific interstitial pneumonia, OP: organizing pneumonia, DAD: diffuse alveolar damage. 
Interstitial changes on HRCT often precede symptoms, but interstitial lung abnormalities do not always progress to clinically significant ILD [23,50]. Interstitial lung disease on HRCT has been reported in between $33 \%$ and $61 \%$ of asymptomatic patients with RA [23,51]. However, uncontrolled arthritis may cause impaired physical activity and may disguise respiratory symptoms.

Lung ultrasonography (LUS) has been a suggested modality to identify ILD by detection of sonographic B-lines. Lung ultrasonography findings have a high sensitivity (89\%-97\%) but varying specificity $(50 \%-97 \%)$ compared to HRCT in patients with RA-ILD [52,53]. However, the etiology of the $B$ lines may be difficult to establish in clinical practice, and differentiation between inflammatory and fibrotic changes is not possible using LUS [54].

\subsection{Pulmonary Function}

Pulmonary function tests (PFTs), including diffusing capacity of the lung for carbon monoxide (DLCO), may detect pulmonary disease. However, the usefulness of PFTs as a screening tool for ILD in RA is limited by the variability within the normal range and by the presence of concomitant emphysema. The results of PFTs among patients with RA-ILD depend on the study cohorts and disease severity.

Abnormal PFT are seen in $45 \%-65 \%$ of patients with RA with or without respiratory symptoms $[33,37,55]$. The patterns include airway obstruction, restrictive patterns, and impaired DLCO. The prevalence of a restrictive pattern is $5 \%-25 \%$; impaired DLCO is seen in approximately $20 \%-45 \%$ of patients with RA [55-57]. Although a large number of patients have abnormal PFTs, most abnormalities remain clinically insignificant and asymptomatic. There are no screening recommendations for lung disease among patients with RA, and it remains a challenge to decide how to manage minor pulmonary function impairment.

\subsection{Bronchoscopy with Bronchoalveolar Lavage}

Bronchoscopy with bronchoalveolar lavage (BAL) can be used to rule out infection as a cause of pulmonary infiltrates and to assess the profile of the inflammatory cells in the lungs. However, reports of cell counts have been ambiguous. Although increased BAL lymphocyte counts have been found, findings are not consistent [30,58,59]. However, these studies generally included few patients with RA-ILD, and larger studies are needed to determine the prognostic and therapeutic significance of BAL cytological differential counts.

\subsection{Histopathology}

The histopathological patterns in RA-ILD are diverse and all patterns of interstitial pneumonia may occur and even overlap. The classification of the idiopathic interstitial pneumonias [60] distinguishes among a number of specific histopathological patterns which are also seen in RA-ILD. A UIP pattern is characterized by heterogeneity with patchy fibrosis with honeycombing and fibroblast foci alternating with areas of normal lung tissue. Non-specific interstitial pneumonia has a uniform appearance with a thickening of the alveolar septa with varying degrees of inflammation and fibrosis. In respiratory bronchiolitis, desquamative interstitial pneumonia and follicular bronchiolitis, peribronchiolar inflammation, and fibrosis are present, whereas organizing pneumonia is dominated by intra-alveolar plugs of connective tissue. Diffuse alveolar damage is an acute form of lung damage similar to adult respiratory distress syndrome.

Findings in biopsy studies of RA-ILD are described below (Table 2). Both UIP and NSIP were the most frequently reported patterns in surgical lung biopsies and autopsy material. Rare patterns include eosinophilic pneumonia, lymphocytic interstitial pneumonia, and obliterative bronchiolitis [30,32,42,61-64]. 
Table 2. Histopathological patterns from surgical lung biopsy and autopsy materials in patients with RA-ILD. UIP: usual interstitial pneumonia, NSIP: non-specific interstitial pneumonia, OP: organizing pneumonia, DAD: diffuse alveolar damage.

\begin{tabular}{|c|c|c|c|c|c|c|c|}
\hline & Number & UIP & NSIP & Bronchiolitis & OP & DAD & Unclassifiable \\
\hline Tansey et al. Histopathology 2004 [61] & 16 & 2 & 7 & 7 & - & - & - \\
\hline Lee et al. Chest 2005 [30] & 18 & 10 & 6 & 2 & - & - & - \\
\hline Yoshinouchi et al. Rheumatology. International. 2005 [62] & 16 & 7 & 7 & - & - & - & 2 \\
\hline Kim et al. Chest 2009 [65] & 14 & 10 & 3 & - & - & - & 1 \\
\hline Nakamura et al. Respiratory Medicine 2012 [32] & 54 & 15 & 16 & 17 & 4 & - & 2 \\
\hline Yousem et al. American Review of Respiratory Disease 1985 [63] & 19 & 5 & 5 & 1 & 6 & 2 & - \\
\hline Tanaka et al. Radiology 2004 [39] & 17 & 2 & 10 & 2 & 2 & 1 & - \\
\hline$N(\%$ of total $)$ & $161(100 \%)$ & $57(35 \%)$ & $54(34 \%)$ & $29(18 \%)$ & $13(8 \%)$ & $3(2 \%)$ & $5(3 \%)$ \\
\hline
\end{tabular}


Rheumatoid arthritis-associated interstitial lung disease may be classified into two different radiological and histopathological phenotypes: (1) fibrotic disease with a UIP pattern and (2) predominantly inflammatory disease with a non-UIP pattern (e.g., NSIP and OP).

Traditionally, histopathology has been regarded as the gold standard in the diagnosis of ILD, but lung biopsies are associated with a significant risk related to the surgical procedure. However, the correlation between radiological and histopathological patterns is high in RA-ILD although studies are small [30,39,65]. Thus, biopsies in the diagnostic work up of RA-ILD should mainly be used in difficult cases with atypical clinical and radiological features. Transbronchial cryobiopsies have emerged as a new diagnostic tool and may be used more often in the future due to the lower associated mortality and high diagnostic yield [66].

\section{Screening for RA-ILD}

Screening for respiratory symptoms should be part of the follow up for RA, and patients should be referred for pulmonary evaluation if symptoms occur. Not only ILD, but also COPD, bronchiectasis, and recurrent infections must be identified and treated. There are no studies validating a specific screening program for RA-ILD.

\section{Differential Diagnosis}

In some cases, lung manifestations may precede the diagnosis of RA. Patients with idiopathic interstitial lung disease should be observed prospectively for signs of systemic disease $[3,67,68]$. Differential diagnostic considerations should also be part of the follow up and not only of the initial diagnostic work up. The evaluation of clinical or subclinical deterioration in patients with RA-ILD is often challenging, and infection and drug-induced pneumonitis are some of the differential diagnosis that should be considered apart from disease progression (Table 3).

Table 3. Differential diagnosis of RA-ILD.

Drug-induced lung toxicities *
Infections ${ }^{* *}$
Bronchiectasis
COPD
Congestive heart failure
Pleural effusions
Malignancy (lung cancer, lymphoma)
Acute exacerbations in RA-ILD
Smoking-related parenchymal lung diseases +
Rheumatoid nodules
$\begin{aligned} & \text { Disease-modifying anti-rheumatic drugs (DMARD) and biologic therapy. }{ }^{* *} \text { Pneumonia and opportunistic infections. } \\ & \text { obstructive pulmonary disease. }\end{aligned}$

However, drug-induced ILD is relatively rare. A large meta-analysis estimated a prevalence of approximately $1 \%$ of patients treated with methotrexate, leflunomide, sulfasalazine or TNF-alpha inhibitors [69]. Disease-modifying anti-rheumatic drugs (DMARDs) are widely used in RA with methotrexate (MTX) as the first-line treatment. Methotrexate is also the drug that is most often suspected to cause pulmonary toxicity, mainly within 6-12 months from treatment initiation [70]. The radiologic pattern in MTX-induced pneumonitis typically resembles the pattern of hypersensitivity pneumonitis with diffuse centrilobular nodules and ground glass opacities. Other radiological ILD patterns are uncommon and more likely related to RA itself [68]. A meta-analysis demonstrated increased risk of lung disease, including infections, with MTX compared to other DMARDS and biological agents [70]. All cases of pneumonitis were reported in studies published prior to 2002. In a small study of 64 patients, Gochuico et al. [23] reported an increased risk of progression of preclinical interstitial changes in 21 patients with RA who received MTX compared to other DMARDS [23]. A systematic literature search found 21 prospective studies of MTX monotherapy but identified only 
15 cases of pneumonitis among 3463 patients receiving low-dose MTX ( $0.43 \%)$ for up to 36.5 months [71]. Recently, a Mexican study showed improved survival among patients with RA-ILD treated with MTX [72]. Thus, the use of MTX in RA-ILD seems to have a fair long-term safety and may even improve survival; this is contrary to the results of older studies.

Biological agents such as TNF-alpha inhibitors are also associated with pulmonary toxicity [69]. Risk factors for lung injury are reported to be older age, concomitant immunosuppressive therapy, and pre-existing ILD [73].

Infections may complicate the use of all immunosuppressants therapies, and the risk increases with the burden of immunosuppression [74]. The dysfunctional immune system in RA and pre-existing lung disease further increase the risk of infections. In a retrospective study of 181 patients with RA-ILD, pneumonia was the most frequently reported condition ( 3.9 per 100 person-years) followed by opportunistic infections (1.5 per 100 person-years). The risk increased with prednisolone doses above $10 \mathrm{mg}$ daily with or without DMARDs. Overall, infection rates were 7.4 per 100 person-years [75].

The risks of fungal and mycobacterial infections and reactivation of latent infections are increased by TNF-alpha inhibitors. Latent tuberculosis should be ruled out by interferon-gamma assays before initiation of therapy [76].

Other differential diagnoses should also be considered. Acute exacerbations of RA-ILD occur with a one-year incidence of $2.8 \%$ and may mimic severe respiratory infections [77]. Occasionally, environmental allergens may complicate the condition by causing hypersensitivity pneumonitis [78]. Patients with RA have an increased risk of heart disease including congestive heart failure with pulmonary edema [79]. Heart failure may present as ground glass opacities and smooth thickening of the intralobular septa on HRCT, complicating the assessment of lung involvement.

Patients with RA are at increased risk of lymphoma and lung cancer compared to the general population, and the risk is related to immunosuppression and autoimmunity [80]. Malignancy may mimic RA-ILD changes in the lung with OP-like consolidations (lung cancer, lymphoma) or nodular interlobular septal thickening (lymphangitis carcinomatosis). Chronic obstructive pulmonary disease is common among patients with RA [4], and other smoking-related lung diseases such as respiratory bronchiolitis-ILD, desquamative interstitial lung disease, and Langerhans cell histiocytosis may be seen in RA. Pleural effusions, bronchiectasis, and rheumatoid nodules are other pulmonary manifestations of RA that are seldom mistaken for ILD but may occur simultaneously.

\section{Treatment}

New treatment strategies for RA, including early and effective DMARDs, have resulted in reduced disease activity, but the optimal treatment of lung involvement is still a dilemma [81]. So far, no randomized controlled trials in RA-ILD have been conducted.

Corticosteroids, azathioprine, and mycophenolate are the most widely used therapeutic options, with rituximab or TNF-alpha inhibitors as alternatives in patients with refractory disease. Treatment response is often better in RA-ILD with an inflammatory pattern. Fibrotic disease, especially RA-UIP, tends to be less responsive and the course of disease is similar to that of idiopathic pulmonary fibrosis (IPF) [82].

It is a challenge to determine if watchful waiting or treatment initiation is the appropriate strategy for RA-ILD. Treatment is mainly initiated in clinically significant disease when there is evidence of disease progression. Symptom assessment and pulmonary function tests, including DLCO, should be part of the follow-up. Follow-up HRCT should be guided by symptoms and pulmonary function deterioration. The optimal follow-up interval is not known and will depend on disease course and treatment. Follow-up every 3-6 months in stable disease is often used in clinical practice [83]. 
It is unknown whether treatment can prevent disease progression in patients with subclinical disease.

Current treatment is empiric and essentially based on immunosuppression. Traditionally, corticosteroids are administrated as a daily oral dose or as pulse courses, and it is tapered over months depending on the tolerability and clinical response [84]. The effect of corticosteroids is believed to be limited to the inflammatory subtypes of RA-ILD such as NSIP and OP $[65,85]$. Other immunosuppressive drugs such as TNF-alfa-inhibitors, methotrexate, azathioprine, mycophenolate mofetil (MMF), and cyclophosphamide are used as maintenance therapy or in corticosteroid resistant cases [84].

In a study from 2013, MMF was shown to stabilize lung function in connective tissue disease-associated ILD (CTD-ILD) including a group of patients with RA $(n=18)$ with progressive decline in forced vital capacity (FVC). The MMF treatment resulted in a trend for FVC increase and was well tolerated [86] which was also reported in previous studies [87,88]. Saketkoo et al. [89] found that MMF improved symptoms and stabilized or improved PFTs in a small mixed CTD cohort that included RA patients. Furthermore, steroids could be tapered.

Treatment of fibrotic CTD-ILD with AZA and MMF resulted in stabilization of lung function in a study from 2016. Mycophenolate mofetil (MMF) seemed to be better tolerated as discontinuation of medication for non-pulmonary side effects was more common in patients on azathioprine (27\%) than on mycophenolate (5\%). The adverse incident rates were similar in the two groups and did not differ on the basis of HRCT patterns [90]. A retrospective study of 40 RA-ILD patients treated with high-dose glucocorticoids, leflunomide or methotrexate showed improvement in FVC after 4 months [91].

In summary, primarily MMF demonstrates some efficacy with stabilization or minor improvement of lung function combined with relatively low toxicity. Both AZA and MTX seem to have less efficacy. Larger clinical trials are needed to clarify their use in RA-ILD.

The use of cyclophosphamide in combination with methylprednisolone has shown some benefit in rapidly progressive, severe ILD and in RA-ILD with extensive UIP, but evidence is based on small retrospective case series [48,92].

Rituximab, a B-cell-depleting anti-CD20 antibody, was used in 700 patients with RA; 56 had RA-ILD prior to rituximab treatment. A total of $68 \%$ of these patients improved or had stable pulmonary function after rituximab [93]. Rituximab was safe and only three patients $(0.4 \%)$ developed ILD after RTX treatment, which may point towards a protective effect of rituximab [93]. A similar response was seen in smaller case series [94]. Thus, rituximab may be useful in patients with CTD-ILD with severe ILD refractory to other forms of immunosuppression [95].

The use of TNF-alpha inhibitor therapy in RA-ILD is limited to small case series with reports of ILD stabilization $[96,97]$.

Non-pharmacological initiatives should always be considered. As in any chronic lung disease, pulmonary rehabilitation is important, and it has been shown to improve walking distance, quality of life, and dyspnea [98]. Pulmonary physiotherapy, including breathing exercises, may be helpful in managing dyspnea and productive cough.

Influenza and pneumococcal vaccination and optimized hand hygiene should be emphasized as tools to prevent infections (345).

Smoking cessation is essential, and advice should be offered to all smokers with RA-ILD as well as those with only RA. Supplementary oxygen can be beneficial as part of palliative care for patients with hypoxemia.

Lung transplantation should be considered in the most severe and progressive cases. Selection of transplant candidates follows the general recommendations [99]. Extra-pulmonary RA manifestations may compromise the patient's functional ability, and side effects of immunosuppression may complicate or contraindicate transplantation. Studies have demonstrated similar one-year survival in patients with RA-ILD as in IPF and scleroderma-associated ILD [100,101]. 
Rheumatoid arthritis-associated interstitial lung disease with a UIP pattern shares radiological and histopathological similarities with IPF, and this raises the question of the role of antifibrotic therapies in the treatment for RA-ILD. A recently published study showed a positive effect of nintedanib on slowing the decline of lung function in a broad range of fibrosing interstitial lung diseases with a progressive phenotype including RA-ILD [102]. Ongoing studies are evaluating another antifibrotic drug, pirfenidone, in RA-ILD and progressive fibrotic ILD [103,104].

\section{Prognosis}

Survival in patients with RA has improved in recent years, but patients with RA-associated ILD still have significantly reduced survival compared to patients with RA alone $[3,49,105]$. Previous RA-ILD studies report a median survival of three to ten years [11,106-108]. More recent studies tend to show longer survival which may be attributed to improved radiological techniques and increased awareness of RA-ILD leading to earlier diagnosis (Table 4). 
Table 4. Reported HRCT patterns and mortality in RA-ILD studies published between 2009 and 2019.

\begin{tabular}{|c|c|c|c|c|c|}
\hline Authors & Institution & Study Period & RA-ILD Cohort Size & HRCT Patterns & Survival \\
\hline $\begin{array}{l}\text { Bongartz et al. Arthritis } \mathcal{E} \\
\text { Rheumatology } 2010 \text { [11] }\end{array}$ & $\begin{array}{c}\text { Population-based incidence } \\
\text { cohort of RA patients in } \\
\text { Rochester, USA }\end{array}$ & 1955-1995 & 46 & Not reported & Median survival 2.6 years \\
\hline $\begin{array}{c}\text { Kim et al. } \\
\text { European Respiratory Journal } \\
2010 \text { [42] }\end{array}$ & $\begin{array}{c}\text { Two referral centers, UCSF and } \\
\text { Mayo Clinic, USA }\end{array}$ & 2001-2008 & 82 & $\begin{array}{c}24 \% \text { UIP } \\
23 \% \text { NSIP } \\
51 \% \text { indeterminate } \\
2 \% \text { other }\end{array}$ & $\begin{array}{l}\text { Median survival } \\
\text { UIP } 3.2 \text { years } \\
\text { Not UIP } 6.6 \text { years }\end{array}$ \\
\hline $\begin{array}{l}\text { Koduri et al. Rheumatology } \\
2010 \text { [106] }\end{array}$ & $\begin{array}{l}\text { ERAS Inception cohort of RA } \\
\text { patients from nine rheumatology } \\
\text { centers in the UK }\end{array}$ & 1986-1998 & 52 & Not reported & Median survival 3 years \\
\hline $\begin{array}{c}\text { Tsuchiya et al. } \\
\text { European Respiratory Journal } \\
2011 \text { [45] }\end{array}$ & Respiratory center, Japan & 1996-2006 & 102 & $\begin{array}{c}56 \% \text { UIP } \\
16 \% \text { NSIP } \\
5 \% \text { OP } \\
5 \% \text { DAD } \\
19 \% \text { combined } \\
\end{array}$ & $\begin{array}{c}\text { Five-year survival } \\
\text { UIP } 36.6 \% \\
\text { NSIP } 98.3 \% \\
\text { OP } 60.0 \% \\
\text { DAD } 20 \%\end{array}$ \\
\hline $\begin{array}{c}\text { Nakamura et al. Respiratory } \\
\text { Medicine } 2012 \text { [32] }\end{array}$ & Referral center, Japan & 1980-2009 & 54 & Not reported & $\begin{array}{l}\text { Ten-year survival 76.6\% } \\
\text { (UIP 52.5\%, NSIP 84.3\%) }\end{array}$ \\
\hline $\begin{array}{l}\text { Solomon et al. Respiratory } \\
\text { Medicine } 2013 \text { [108] }\end{array}$ & $\begin{array}{l}\text { Two referral centers. } \\
\text { National Jewish and } \\
\text { Mayo Clinic, USA }\end{array}$ & 1977-1999 & 48 & Not reported & $\begin{array}{l}\text { Median survival } \\
45 \text { months }\end{array}$ \\
\hline Assayag et al. Radiology 2014 [46] & $\begin{array}{c}\text { Three referral centers, USA and } \\
\text { Korea }\end{array}$ & 1997-2011 & 69 & $\begin{array}{c}29 \% \text { definite UIP } \\
26 \% \text { possible UIP } \\
45 \% \text { inconsistent with UIP }\end{array}$ & Not reported \\
\hline Kelly et al. Rheumatology 2014 [14] & $\begin{array}{l}\text { BRILL network, } \\
\text { Rheumatology centers in the UK }\end{array}$ & 1987-2012 & 230 & $\begin{array}{c}65 \% \text { UIP } \\
24 \% \text { NSIP } \\
\text { OP } 6 \% \\
\text { Overlap syndromes } 6 \%\end{array}$ & Not reported \\
\hline $\begin{array}{l}\text { Nurmi et al. } \\
\text { BMC Pulmonary Medicine } \\
\text { 2016 [109] }\end{array}$ & Referral center, Kuopio, Finland & 2000-2014 & 59 & $\begin{array}{c}59 \% \text { UIP } \\
14 \% \text { NSIP } \\
12 \% \text { OP } \\
15 \% \text { other }\end{array}$ & $\begin{array}{l}\text { Median survival } \\
\text { UIP } 92 \text { months } \\
\text { Not UIP } \\
137 \text { months }\end{array}$ \\
\hline
\end{tabular}


Table 4. Cont.

\begin{tabular}{|c|c|c|c|c|c|}
\hline Authors & Institution & Study Period & RA-ILD Cohort Size & HRCT Patterns & Survival \\
\hline $\begin{array}{c}\text { Solomon et al. } \\
\text { European Respiratory Journal } \\
2016 \text { [107] }\end{array}$ & $\begin{array}{c}\text { Referral center, National Jewish, } \\
\text { USA }\end{array}$ & 1995-2013 & 137 & $\begin{array}{l}79 \% \text { UIP } \\
21 \% \text { NSIP }\end{array}$ & $\begin{array}{l}\text { Median survival } \\
10.35 \text { years } \\
\text { UIP } 10.2 \text { years } \\
\text { NSIP } 13.6 \text { years }\end{array}$ \\
\hline $\begin{array}{l}\text { Morisset et al. Respiratory } \\
\text { Medicine } 2017 \text { [47] }\end{array}$ & $\begin{array}{l}\text { Four referral centers, } \\
\text { USA, Korea, } \\
\text { Italy }\end{array}$ & NA & 309 & $\begin{array}{c}24 \% \text { UIP } \\
16 \% \text { possible UIP } \\
60 \% \text { inconsistent with UIP }\end{array}$ & $\begin{array}{c}\text { Three-year mortality: } \\
\text { GAP stage } 1 \\
1.9 \% \\
\text { GAP stage } 217.6 \% \\
\text { GAP stage } 350.3 \%\end{array}$ \\
\hline $\begin{array}{c}\text { Nurmi et al. } \\
\text { BMC Pulmonary Medicine } \\
2017 \text { [110] }\end{array}$ & Referral center, Kuopio, Finland & 2000-2014 & 59 & $\begin{array}{l}\text { Reported in a previous } \\
\text { study }\end{array}$ & $\begin{array}{c}\text { Median survival } \\
\text { GAP stage 1, } 152 \text { months, } \\
\text { GAP stage } 2,61 \text { months } \\
\text { Three-year mortality } \\
\text { GAP stage } 1,17.6 \% \\
\text { GAP stage } 2,27.3 \%\end{array}$ \\
\hline $\begin{array}{l}\text { Rojas-Serrano et al. Clinical } \\
\text { Rheumatology } 2017 \text { [72] }\end{array}$ & Mexico & 2004-2015 & 78 & $\begin{array}{c}26 \% \text { UIP } \\
36 \% \text { NSIP } \\
19 \% \text { LIP } \\
6 \% \text { OP } \\
36 \% \text { overlap }\end{array}$ & Median survival 5.8 years \\
\hline $\begin{array}{c}\text { Yunt et al. } \\
\text { Respiratory Medicine 2017 [43] }\end{array}$ & $\begin{array}{c}\text { Referral center, } \\
\text { National Jewish, USA }\end{array}$ & 1995-2014 & 158 & $\begin{array}{c}63 \% \text { definite UIP } \\
15 \% \text { possible UIP } \\
22 \% \text { NSIP }\end{array}$ & $\begin{array}{l}\text { Median survival } \\
\text { Definite UIP } 2.77 \text { years } \\
\text { Possible UIP 6.14 years } \\
\text { NSIP incalculable }\end{array}$ \\
\hline $\begin{array}{l}\text { Zamora-Legoff et al. } \\
\text { Rheumatology } 2017 \text { [40] }\end{array}$ & Referral center, Mayo Clinic, USA & 1998-2014 & 181 & $\begin{array}{l}54 \% \text { UIP } \\
40 \% \text { NSIP } \\
6 \% \text { OP }\end{array}$ & $\begin{array}{c}\text { Five-year survival 59.7\%, } \\
\text { no difference among } \\
\text { HRCT groups }\end{array}$ \\
\hline
\end{tabular}


Table 4. Cont

\begin{tabular}{|c|c|c|c|c|c|}
\hline Authors & Institution & Study Period & RA-ILD Cohort Size & HRCT Patterns & Survival \\
\hline $\begin{array}{c}\text { Zhang et al. } \\
\text { Clinical Rheumatology } 2017 \text { [38] }\end{array}$ & China & 2008-2013 & 237 & $\begin{array}{l}18.6 \% \text { UIP } \\
57.8 \% \text { NSIP }\end{array}$ & Not reported \\
\hline $\begin{array}{c}\text { Juge et al. } \\
\text { New England Journal of Medicine } \\
2018 \text { [8] }\end{array}$ & $\begin{array}{l}\text { France, China, Greece, Japan, } \\
\text { Mexico, the Netherlands, } \\
\text { and USA }\end{array}$ & NA & 620 & $\begin{array}{l}41 \% \text { UIP/possible UIP } \\
59 \% \text { inconsistent with UIP }\end{array}$ & Not reported \\
\hline $\begin{array}{l}\text { Nurmi et al. } \\
\text { Respiratory Medicine 2018 [44] }\end{array}$ & Referral center, Kuopio, Finland & 2000-2014 & 60 & $\begin{array}{l}\text { Reported in a previous } \\
\text { study }\end{array}$ & Not reported \\
\hline $\begin{array}{l}\text { Sparks et al. Arthritis } \mathcal{E} \\
\text { Rheumatology } 2019 \text { [111] }\end{array}$ & BRASS cohort, USA & $2003-2016$ & 85 & $\begin{array}{c}49 \% \text { fibrotic NSIP } \\
32 \% \text { cellular NSIP } \\
19 \% \text { UIP/AIP/DAD }\end{array}$ & $\begin{array}{l}37.6 \% \text { died during } \\
\text { follow-up }\end{array}$ \\
\hline
\end{tabular}

GAP: Gender, age and physiology score. 
Previous studies have reported UIP as the predominant radiological pattern and predictor of mortality [14,42]; however, recent studies report a UIP proportion of $40 \%-54 \%$ [40,47]. A recent study showed that radiology-based prediction models in RA-ILD can identify patients with a progressive fibrosis phenotype [112], and that the visual extent of ILD in combination with FVC values, as previously seen in scleroderma [113], predicts outcome in RA-ILD. Morisset et al. [47] showed that the addition of HRCT patterns to the ILD-GAP prediction model did not improve its performance.

Solomon et al. [107] showed that pulmonary physiology independently predicted mortality, but baseline HRCT patterns did not. These findings reflect the heterogeneous and often unpredictable disease behavior in RA-ILD.

\section{Future Directions for RA-ILD}

Rheumatoid arthritis-associated interstitial lung disease remains a challenge for clinicians due to the fact of its heterogeneity and variable course of disease. In recent years, our knowledge of risk factors, pathogenesis, and diagnostic approaches in RA-ILD has increased, but major gaps are still present (Table 5). Expert opinion, case series, and retrospective studies constitute the foundation for treatment recommendations. The first randomized controlled trials are ongoing with results expected in the end of 2019 and 2020, and this may result in the emergence of the first evidence-based treatment options in RA-ILD.

Table 5. Future research needs in RA-ILD.

- Deeper insights into the pathogenesis of RA-ILD and its relationship to the pathogenesis of other ILDs

- Better understanding of inflammatory versus fibrotic phenotypes in RA-ILD

- $\quad$ Possible benefits of computerized automatized CT

- Potential benefits of histopathologic evaluation of the degree of inflammation and fibrosis

- Potential benefits of combination therapy with anti-inflammatory and antifibrotic drugs

- $\quad$ Deeper insight into genetic phenotyping and tailoring of therapy

- $\quad$ Potential benefits of improved smoking cessation programs for all RA patients

\section{Conclusions}

Rheumatoid arthritis-associated interstitial lung disease is a serious complication of RA contributing to significantly increased morbidity and mortality. Infections, drug toxicity, and other respiratory and cardiac diseases are important differential diagnoses and should be considered in the diagnostic work up of patients with RA. The predominant HRCT and histopathology patterns are UIP or NSIP. There is no evidence-based therapy in RA-ILD. Immunosuppressants remain the mainstay of therapy, but ongoing studies are exploring the role of antifibrotic therapy in patients with progressive fibrotic ILD.

Author Contributions: For research articles with several authors, a short paragraph specifying their individual contributions must be provided. The following statements should be used "conceptualization, E.B.; methodology, E.B., J.M., S.K.-W., T.S.P., and C.H.; writing-original draft preparation, E.B., J.M., S.K.-W., T.S.P., and C.H.; writing -review and editing, E.B., J.M., S.K.-W., T.S.P., and C.H.; visualization, E.B., and J.M.; supervision, E.B., C.H; project administration, E.B.

Funding: This research received no external funding.

Conflicts of Interest: The authors declare no conflict of interest.

\section{References}

1. Young, A.; Koduri, G.; Batley, M.; Kulinskaya, E.; Gough, A.; Norton, S.; Dixey, J. Mortality in rheumatoid arthritis. Increased in the early course of disease, in ischaemic heart disease and in pulmonary fibrosis. Rheumatology 2007, 46, 350-357. [CrossRef] [PubMed] 
2. Sparks, J.A.; Chang, S.C.; Liao, K.P.; Lu, B.; Fine, A.R.; Solomon, D.H.; Costenbader, K.H.; Karlson, E.W. Rheumatoid Arthritis and Mortality among Women during 36 Years of Prospective Follow-Up: Results from the Nurses' Health Study. Arthritis Care Res. 2016, 68, 753-762. [CrossRef] [PubMed]

3. Hyldgaard, C.; Hilberg, O.; Pedersen, A.B.; Ulrichsen, S.P.; Løkke, A.; Bendstrup, E.; Ellingsen, T. A population-based cohort study of rheumatoid arthritis-associated interstitial lung disease: Comorbidity and mortality. Ann. Rheum. Dis. 2017, 76, 1700-1706. [CrossRef] [PubMed]

4. Hyldgaard, C.; Bendstrup, E.; Pedersen, A.B.; Ulrichsen, S.P.; Løkke, A.; Hilberg, O.; Ellingsen, T. Increased mortality among patients with rheumatoid arthritis and COPD: A population-based study. Respir. Med. 2018, 140, 101-107. [CrossRef]

5. Restrepo, J.F.; del Rincón, I.; Battafarano, D.F.; Haas, R.W.; Doria, M.; Escalante, A. Clinical and laboratory factors associated with interstitial lung disease in rheumatoid arthritis. Clin. Rheumatol. 2015, 34, 1529-1536. [CrossRef]

6. Olson, A.L.; Swigris, J.J.; Sprunger, D.B.; Fischer, A.; Fernandez-Perez, E.R.; Solomon, J.; Murphy, J.; Cohen, M.; Raghu, G.; Brown, K.K. Rheumatoid Arthritis-Interstitial Lung Disease-associated Mortality. Am. J. Respir. Crit. Care Med. 2010, 183, 372-378. [CrossRef]

7. Raimundo, K.; Solomon, J.J.; Olson, A.L.; Kong, A.M.; Cole, A.L.; Fischer, A.; Swigris, J.J. Rheumatoid Arthritis-Interstitial Lung Disease in the United States: Prevalence, Incidence, and Healthcare Costs and Mortality. J. Rheumatol. 2019, 46, 360-369. [CrossRef]

8. Juge, P.-A.; Lee, J.S.; Ebstein, E.; Furukawa, H.; Dobrinskikh, E.; Gazal, S.; Kannengiesser, C.; Ottaviani, S.; Oka, S.; Tohma, S.; et al. MUC5B Promoter Variant and Rheumatoid Arthritis with Interstitial Lung Disease. N. Engl. J. Med. 2018, 379, 2209-2219. [CrossRef]

9. Turesson, C.; O'Fallon, W.M.; Crowson, C.S.; Gabriel, S.E.; Matteson, E.L. Extra-articular disease manifestations in rheumatoid arthritis: Incidence trends and risk factors over 46 years. Ann. Rheum. Dis. 2003, 62, 722-727. [CrossRef]

10. Turesson, C.; Jacobsson, L.T.H. Epidemiology of extra-articular manifestations in rheumatoid arthritis. Scand. J. Rheumatol. 2004, 33, 65-72. [CrossRef]

11. Bongartz, T.; Nannini, C.; Medina-Velasquez, Y.F.; Achenbach, S.J.; Crowson, C.S.; Ryu, J.H.; Vassallo, R.; Gabriel, S.E.; Matteson, E.L. Incidence and mortality of interstitial lung disease in rheumatoid arthritis: A population-based study. Arthritis Rheum. 2010, 62, 1583-1591. [CrossRef] [PubMed]

12. Doyle, T.J.; Patel, A.S.; Hatabu, H.; Nishino, M.; Wu, G.; Osorio, J.C.; Golzarri, M.F.; Traslosheros, A.; Chu, S.G.; Frits, M.L.; et al. Detection of rheumatoid arthritis-interstitial lung disease is enhanced by serum biomarkers. Am. J. Respir. Crit. Care Med. 2015, 191, 1403-1412. [CrossRef] [PubMed]

13. Svendsen, A.J.; Junker, P.; Houen, G.; Kyvik, K.O.; Nielsen, C.; Skytthe, A.; Holst, R. Incidence of Chronic Persistent Rheumatoid Arthritis and the Impact of Smoking: A Historical Twin Cohort Study. Arthritis Care Res. 2017, 69, 616-624. [CrossRef] [PubMed]

14. Kelly, C.A.; Saravanan, V.; Nisar, M.; Arthanari, S.; Woodhead, F.A.; Price-Forbes, A.N.; Dawson, J.; Sathi, N.; Ahmad, Y.; Koduri, G.; et al. Rheumatoid arthritis-related interstitial lung disease: Associations, prognostic factors and physiological and radiological characteristics-a large multicentre UK study. Rheumatology 2014, 53, 1676-1682. [CrossRef]

15. Gregersen, P.K.; Silver, J.; Winchester, R.J. The shared epitope hypothesis. An approach to understanding the molecular genetics of susceptibility to rheumatoid arthritis. Arthritis Rheum. 1987, 30, 1205-1213. [CrossRef]

16. Charles, P.J.; Sweatman, M.C.; Markwick, J.R.; Maini, R.N. HLA-B40: A marker for susceptibility to lung disease in rheumatoid arthritis. Dis. Markers 1991, 9, 97-101.

17. Scott, T.E.; Wise, R.A.; Hochberg, M.C.; Wigley, F.M. HLA-DR4 and pulmonary dysfunction in rheumatoid arthritis. Am. J. Med. 1987, 82, 765-771. [CrossRef]

18. Sugiyama, Y.; Ohno, S.; Kano, S.; Maeda, H.; Kitamura, S. Diffuse Panbronchiolitis and Rheumatoid Arthritis: A Possible Correlation with HLA-B54. Intern. Med. 1994, 33, 612-614. [CrossRef]

19. Demoruelle, M.K.; Deane, K.D.; Holers, V.M. When and where does inflammation begin in rheumatoid arthritis? Curr. Opin. Rheumatol. 2014, 26, 64-71. [CrossRef]

20. Scally, S.W.; Petersen, J.; Law, S.C.; Dudek, N.L.; Nel, H.J.; Loh, K.L.; Wijeyewickrema, L.C.; Eckle, S.B.G.; van Heemst, J.; Pike, R.N.; et al. A molecular basis for the association of the HLA-DRB1 locus, citrullination, and rheumatoid arthritis. J. Exp. Med. 2013, 210, 2569-2582. [CrossRef] 
21. Makrygiannakis, D.; Hermansson, M.; Ulfgren, A.-K.; Nicholas, A.P.; Zendman, A.J.W.; Eklund, A.; Grunewald, J.; Skold, C.M.; Klareskog, L.; Catrina, A.I. Smoking increases peptidylarginine deiminase 2 enzyme expression in human lungs and increases citrullination in BAL cells. Ann. Rheum. Dis. 2008, 67, 1488-1492. [CrossRef] [PubMed]

22. Meroni, R.; Piscitelli, D.; Bonetti, F.; Zambaldi, M.; Guccione, A.A.; Pillastrini, P. Rasch analysis of the Italian version of fear avoidance beliefs questionnaire (FABQ-I). Disabil. Rehabil. 2015, 37, 151-157. [CrossRef] [PubMed]

23. Gochuico, B.R.; Avila, N.A.; Chow, C.K.; Novero, L.J.; Wu, H.-P.P.; Ren, P.; MacDonald, S.D.; Travis, W.D.; Stylianou, M.P.; Rosas, I.O. Progressive preclinical interstitial lung disease in rheumatoid arthritis. Arch. Intern. Med. 2008, 168, 159-166. [CrossRef] [PubMed]

24. Paulin, F.; Babini, A.; Mamani, M.; Mercado, J.; Caro, F. Practical Approach to the Evaluation and Management of Rheumatoid Arthritis-Interstitial Lung Disease Based on its Proven and Hypothetical Mechanisms. Rev. Investig. Clin. 2017, 69, 235-242. [CrossRef]

25. Paulin, F.; Doyle, T.J.; Fletcher, E.A.; Ascherman, D.P.; Rosas, I.O. Rheumatoid Arthritis-Associated Interstitial Lung Disease and Idiopathic Pulmonary Fibrosis: Shared Mechanistic and Phenotypic Traits Suggest Overlapping Disease Mechanisms. Rev. Investig. Clin. 2015, 67, 280-286.

26. Juge, P.-A.; Borie, R.; Kannengiesser, C.; Gazal, S.; Revy, P.; Wemeau-Stervinou, L.; Debray, M.-P.; Ottaviani, S.; Marchand-Adam, S.; Nathan, N.; et al. Shared genetic predisposition in rheumatoid arthritis-interstitial lung disease and familial pulmonary fibrosis. Eur. Respir. J. 2017, 49, 1602314. [CrossRef]

27. Ley, B.; Newton, C.A.; Arnould, I.; Elicker, B.M.; Henry, T.S.; Vittinghoff, E.; Golden, J.A.; Jones, K.D.; Batra, K.; Torrealba, J.; et al. The MUC5B promoter polymorphism and telomere length in patients with chronic hypersensitivity pneumonitis: An observational cohort-control study. Lancet Respir. Med. 2017, 5 , 639-647. [CrossRef]

28. Behr, J.; Kreuter, M.; Hoeper, M.M.; Wirtz, H.; Klotsche, J.; Koschel, D.; Andreas, S.; Claussen, M.; Grohé, C.; Wilkens, H.; et al. Management of patients with idiopathic pulmonary fibrosis in clinical practice: The INSIGHTS-IPF registry. Eur. Respir. J. 2015, 46, 186-196. [CrossRef]

29. Dawson, J.K.; Fewins, H.E.; Desmond, J.; Lynch, M.P.; Graham, D.R. Fibrosing alveolitis in patients with rheumatoid arthritis as assessed by high resolution computed tomography, chest radiography, and pulmonary function tests. Thorax 2001, 56, 622-627. [CrossRef]

30. Lee, H.-K.K.; Kim, D.S.; Yoo, B.; Seo, J.B.; Rho, J.-Y.Y.; Colby, T.V.; Kitaichi, M. Histopathologic pattern and clinical features of rheumatoid arthritis-associated interstitial lung disease. Chest 2005, 127, 2019-2027. [CrossRef]

31. Skare, T.L.; Nakano, I.; Escuissiato, D.L.; Batistetti, R.; de Oliveira Rodrigues, T.; Silva, M.B. Pulmonary changes on high-resolution computed tomography of patients with rheumatoid arthritis and their association with clinical, demographic, serological and therapeutic variables. Rev. Bras. Reumatol. 2011, 51, 325-337. [PubMed]

32. Nakamura, Y.; Suda, T.; Kaida, Y.; Kono, M.; Hozumi, H.; Hashimoto, D.; Enomoto, N.; Fujisawa, T.; Inui, N.; Imokawa, S.; et al. Rheumatoid lung disease: Prognostic analysis of 54 biopsy-proven cases. Respir. Med. 2012, 106, 1164-1169. [CrossRef] [PubMed]

33. Bilgici, A.; Ulusoy, H.; Kuru, O.; Celenk, C.; Ünsal, M.; Danac1, M. Pulmonary involvement in rheumatoid arthritis. Rheumatol. Int. 2005, 25, 429-435. [CrossRef] [PubMed]

34. Zrour, S.H.; Touzi, M.; Bejia, I.; Golli, M.; Rouatbi, N.; Sakly, N.; Younes, M.; Tabka, Z.; Bergaoui, N. Correlations between high-resolution computed tomography of the chest and clinical function in patients with rheumatoid arthritis. Jt. Bone Spine 2005, 72, 41-47. [CrossRef] [PubMed]

35. Leonel, D.; Lucia, C.A.M.; Martha-Alicia, H.; Blanca, M. Pulmonary function test: Its correlation with pulmonary high-resolution computed tomography in patients with rheumatoid arthritis. Rheumatol. Int. 2012, 32, 2111-2116. [CrossRef]

36. Youssef, A.A.; Machaly, S.A.; El-Dosoky, M.E.; El-Maghraby, N.M. Respiratory symptoms in rheumatoid arthritis: Relation to pulmonary abnormalities detected by high-resolution CT and pulmonary functional testing. Rheumatol. Int. 2012, 32, 1985-1995. [CrossRef]

37. Kanat, F.; Levendoglu, F.; Teke, T. Radiological and functional assessment of pulmonary involvement in the rheumatoid arthritis patients. Rheumatol. Int. 2007, 27, 459-466. [CrossRef] 
38. Zhang, Y.; Li, H.; Wu, N.; Dong, X.; Zheng, Y. Retrospective study of the clinical characteristics and risk factors of rheumatoid arthritis-associated interstitial lung disease. Clin. Rheumatol. 2017, 36, 817-823. [CrossRef]

39. Tanaka, N.; Kim, J.S.; Newell, J.D.; Brown, K.K.; Cool, C.D.; Meehan, R.; Emoto, T.; Matsumoto, T.; Lynch, D.A. Rheumatoid Arthritis-related Lung Diseases: CT Findings. Radiology 2004, 232, 81-91. [CrossRef]

40. Zamora-Legoff, J.A.; Krause, M.L.; Crowson, C.S.; Ryu, J.H.; Matteson, E.L. Patterns of interstitial lung disease and mortality in rheumatoid arthritis. Rheumatology 2017, 56, 344-350. [CrossRef]

41. Mori, S.; Cho, I.; Koga, Y.; Sugimoto, M. Comparison of pulmonary abnormalities on high-resolution computed tomography in patients with early versus longstanding rheumatoid arthritis. J. Rheumatol. 2008, 35, 1513-1521. [PubMed]

42. Kim, E.J.; Elicker, B.M.; Maldonado, F.; Webb, W.R.; Ryu, J.H.; Van Uden, J.H.; Lee, J.S.; King, T.E.; Collard, H.R. Usual interstitial pneumonia in rheumatoid arthritis-associated interstitial lung disease. Eur. Respir. J. 2010, 35, 1322-1328. [CrossRef] [PubMed]

43. Yunt, Z.X.; Chung, J.H.; Hobbs, S.; Fernandez-Perez, E.R.; Olson, A.L.; Huie, T.J.; Keith, R.C.; Janssen, W.J.; Goldstein, B.L.; Lynch, D.A.; et al. High resolution computed tomography pattern of usual interstitial pneumonia in rheumatoid arthritis-associated interstitial lung disease: Relationship to survival. Respir. Med. 2017, 126, 100-104. [CrossRef] [PubMed]

44. Nurmi, H.M.; Kettunen, H.-P.; Suoranta, S.-K.; Purokivi, M.K.; Kärkkäinen, M.S.; Selander, T.A.; Kaarteenaho, R.L. Several high-resolution computed tomography findings associate with survival and clinical features in rheumatoid arthritis-associated interstitial lung disease. Respir. Med. 2018, 134, 24-30. [CrossRef]

45. Tsuchiya, Y.; Takayanagi, N.; Sugiura, H.; Miyahara, Y.; Tokunaga, D.; Kawabata, Y.; Sugita, Y. Lung diseases directly associated with rheumatoid arthritis and their relationship to outcome. Eur. Respir. J. 2011, 37, 1411-1417. [CrossRef]

46. Assayag, D.; Elicker, B.M.; Urbania, T.H.; Colby, T.V.; Kang, B.H.; Ryu, J.H.; King, T.E.; Collard, H.R.; Kim, D.S.; Lee, J.S. Rheumatoid Arthritis-associated Interstitial Lung Disease: Radiologic Identification of Usual Interstitial Pneumonia Pattern. Radiology 2014, 270, 583-588. [CrossRef]

47. Morisset, J.; Vittinghoff, E.; Lee, B.Y.; Tonelli, R.; Hu, X.; Elicker, B.M.; Ryu, J.H.; Jones, K.D.; Cerri, S.; Manfredi, A.; et al. The performance of the GAP model in patients with rheumatoid arthritis associated interstitial lung disease. Respir. Med. J. 2017, 127, 51-56. [CrossRef]

48. Kelly, C.; Palmer, E.; Gordon, J.; Woodhead, F.; Nisar, M.; Arthanari, S.; Forbes-Price, A.; Middleton, D.; Dempsey, O.; Dawson, J.; et al. OP0037 Pulsed Cyclophosphamide in the Treatment of Rheumatoid Arthritis-Related Interstitial Lung Disease (RA-ILD). Ann. Rheum. Dis. 2014, 73, 74. [CrossRef]

49. Zhang, Y.; Lu, N.; Peloquin, C.; Dubreuil, M.; Neogi, T.; Aviña-Zubieta, J.A.; Rai, S.K.; Choi, H.K. Improved survival in rheumatoid arthritis: A general population-based cohort study. Ann. Rheum. Dis. 2017, 76, 408-413. [CrossRef]

50. Dawson, J.K.; Fewins, H.E.; Desmond, J.; Lynch, M.P.; Graham, D.R. Predictors of progression of HRCT diagnosed fibrosing alveolitis in patients with rheumatoid arthritis. Ann. Rheum. Dis. 2002, 61, 517-521. [CrossRef]

51. Chen, J.; Shi, Y.; Wang, X.; Huang, H.; Ascherman, D. Asymptomatic Preclinical Rheumatoid Arthritis-Associated Interstitial Lung Disease. Clin. Dev. Immunol. 2013, 2013, 10-15. [CrossRef] [PubMed]

52. Cogliati, C.; Antivalle, M.; Torzillo, D.; Birocchi, S.; Norsa, A.; Bianco, R.; Costantino, G.; Ditto, M.C.; Battellino, M.; Sarzi Puttini, P.C.; et al. Standard and pocket-size lung ultrasound devices can detect interstitial lung disease in rheumatoid arthritis patients. Rheumatology 2014, 53, 1497-1503. [CrossRef] [PubMed]

53. Moazedi-Fuerst, F.C.; Kielhauser, S.M.; Scheidl, S.; Tripolt, N.J.; Lutfi, A.; Yazdani-Biuki, B.; Dejaco, C.; Graninger, W.B. Ultrasound screening for interstitial lung disease in rheumatoid arthritis. Clin. Exp. Rheumatol. 2014, 32, 199-203. [PubMed]

54. Wang, Y.; Gargani, L.; Barskova, T.; Furst, D.E.; Cerinic, M.M. Usefulness of lung ultrasound B-lines in connective tissue disease-associated interstitial lung disease: A literature review. Arthritis Res. Ther. 2017, 19, 206. [CrossRef] [PubMed]

55. Avnon, L.S.; Manzur, F.; Bolotin, A.; Heimer, D.; Flusser, D.; Buskila, D.; Sukenik, S.; Abu-Shakra, M. Pulmonary functions testing in patients with rheumatoid arthritis. Isr. Med. Assoc. J. 2009, 11, 83-87. 
56. Pappas, D.A.; Giles, J.T.; Connors, G.; Lechtzin, N.; Bathon, J.M.; Danoff, S.K. Respiratory symptoms and disease characteristics as predictors of pulmonary function abnormalities in patients with rheumatoid arthritis: An observational cohort study. Arthritis Res. Ther. 2010, 12, R104. [CrossRef]

57. Robles-Perez, A.; Luburich, P.; Rodriguez-Sanchon, B.; Dorca, J.; Nolla, J.M.; Molina-Molina, M.; Narvaez-Garcia, J. Preclinical lung disease in early rheumatoid arthritis. Chronic Respir. Dis. 2016, 13, 75-81. [CrossRef]

58. Kolarz, G.; Scherak, O.; Popp, W.; Ritschka, L.; Thumb, N.; Wottawa, A.; Zwick, H. Bronchoalveolar lavage in rheumatoid arthritis. Br. J. Rheumatol. 1993, 32, 556-561. [CrossRef]

59. Popp, W.; Ritschka, L.; Scherak, O.; Braun, O.; Kolarz, G.; Rauscher, H.; Zwick, H. Bronchoalveolar lavage in rheumatoid arthritis and secondary sjögren's syndrome. Lung 1990, 168, 221-231. [CrossRef]

60. Travis, W.D.; Costabel, U.; Hansell, D.M.; King, T.E.; Lynch, D.A.; Nicholson, A.G.; Ryerson, C.J.; Ryu, J.H.; Selman, M.; Wells, A.U.; et al. An Official American Thoracic Society/European Respiratory Society Statement: Update of the International Multidisciplinary Classification of the Idiopathic Interstitial Pneumonias. Am. J. Respir. Crit. Care Med. 2013, 188, 733-748. [CrossRef]

61. Tansey, D.; Wells, A.U.; Colby, T.V.; Ip, S.; Nikolakoupolou, A.; Bois, R.M.; Hansell, D.M.; Nicholson, A.G. Variations in histological patterns of interstitial pneumonia.pdf. Histopathology 2004, 44, 585-596. [CrossRef] [PubMed]

62. Yoshinouchi, T.; Ohtsuki, Y.; Fujita, J.; Yamadori, I.; Bandoh, S.; Ishida, T.; Ueda, R. Nonspecific interstitial pneumonia pattern as pulmonary involvement of rheumatoid arthritis. Rheumatol. Int. 2005, 26, $121-125$. [CrossRef] [PubMed]

63. Yousem, S.A.; Colby, T.V.; Carrington, C.B. Lung biopsy in rheumatoid arthritis. Am. Rev. Respir. Dis. 1985, 131, 770-777.

64. Lin, E.; Limper, A.H.; Moua, T. Obliterative bronchiolitis associated with rheumatoid arthritis: Analysis of a single-center case series. BMC Pulm. Med. 2018, 18, 105. [CrossRef] [PubMed]

65. Kim, E.J.; Collard, H.R.; King, T.E. Rheumatoid arthritis-associated interstitial lung disease: The relevance of histopathologic and radiographic pattern. Chest 2009, 136, 1397-1405. [CrossRef] [PubMed]

66. Iftikhar, I.H.; Alghothani, L.; Sardi, A.; Berkowitz, D.; Musani, A.I. Transbronchial Lung Cryobiopsy and Video-assisted Thoracoscopic Lung Biopsy in the Diagnosis of Diffuse Parenchymal Lung Disease. A Meta-analysis of Diagnostic Test Accuracy. Ann. Am. Thorac. Soc. 2017, 14, 1197-1211. [CrossRef]

67. Kono, M.; Nakamura, Y.; Yoshimura, K.; Enomoto, Y.; Oyama, Y.; Hozumi, H.; Enomoto, N.; Fujisawa, T.; Inui, N.; Hamada, E.; et al. Nonspecific interstitial pneumonia preceding diagnosis of collagen vascular disease. Respir. Med. 2016, 117, 40-47. [CrossRef]

68. Kalinova, D.; Kolarov, Z.; Rashkov, R. Organising pneumonia-The first manifestation of rheumatoid arthritis. Reumatologia 2017, 55, 314-317. [CrossRef]

69. Roubille, C.; Haraoui, B. Interstitial lung diseases induced or exacerbated by DMARDS and biologic agents in rheumatoid arthritis: A systematic literature review. Semin. Arthritis Rheum. 2014, 43, 613-626. [CrossRef]

70. Conway, R.; Low, C.; Coughlan, R.J.; O'Donnell, M.J.; Carey, J.J. Methotrexate and lung disease in rheumatoid arthritis: A meta-analysis of randomized controlled trials. Arthritis Rheumatol. 2014, 66, 803-812. [CrossRef]

71. Salliot, C.; Van Der Heijde, D. Long-term safety of methotrexate monotherapy in patients with rheumatoid arthritis: A systematic literature research. Ann. Rheum. Dis. 2009, 68, 1100-1104. [CrossRef]

72. Rojas-Serrano, J.; Herrera-Bringas, D.; Pérez-Román, D.I.; Pérez-Dorame, R.; Mateos-Toledo, H.; Mejía, M. Rheumatoid arthritis-related interstitial lung disease (RA-ILD): Methotrexate and the severity of lung disease are associated to prognosis. Clin. Rheumatol. 2017, 36, 1493-1500. [CrossRef]

73. Perez-Alvarez, R.; Perez-de-Lis, M.; Diaz-Lagares, C.; Pego-Reigosa, J.M.; Retamozo, S.; Bove, A.; Brito-Zeron, P.; Bosch, X.; Ramos-Casals, M. Interstitial Lung Disease Induced or Exacerbated by TNF-Targeted Therapies: Analysis of 122 Cases. Semin. Arthritis Rheum. 2011, 41, 256-264. [CrossRef]

74. Lahiri, M.; Dixon, W.G. Risk of infection with biologic antirheumatic therapies in patients with rheumatoid arthritis. Best Pract. Res. Clin. Rheumatol. 2015, 29, 290-305. [CrossRef]

75. Singh, J.A.; Cameron, C.; Noorbaloochi, S.; Cullis, T.; Tucker, M.; Christensen, R.; Ghogomu, E.T.; Coyle, D.; Clifford, T.; Tugwell, P.; et al. Risk of serious infection in biological treatment of patients with rheumatoid arthritis: A systematic review and meta-analysis. Lancet 2015, 386, 258-265. [CrossRef] 
76. Zamora-Legoff, J.A.; Krause, M.L.; Crowson, C.S.; Ryu, J.H.; Matteson, E.L. Risk of serious infection in patients with rheumatoid arthritis-associated interstitial lung disease. Clin. Rheumatol. 2016, 35, 2585-2589. [CrossRef]

77. Hozumi, H.; Nakamura, Y.; Johkoh, T.; Sumikawa, H.; Colby, T.V.; Kono, M.; Hashimoto, D.; Enomoto, N.; Fujisawa, T.; Inui, N.; et al. Acute exacerbation in rheumatoid arthritis-associated interstitial lung disease: A retrospective case control study. BMJ Open 2013, 3, e003132. [CrossRef]

78. Hamblin, M.J.; Horton, M.R. Rheumatoid Arthritis-Associated Interstitial Lung Disease: Diagnostic Dilemma. Pulm. Med. 2011, 2011. [CrossRef]

79. Løgstrup, B.B.; Ellingsen, T.; Pedersen, A.B.; Kjærsgaard, A.; Bøtker, H.E.; Maeng, M. Heart Failure and Ischemic Heart Disease in Patients with Rheumatoid Arthritis. J. Am. Coll. Cardiol. 2017, 70, 3069-3071. [CrossRef]

80. Simon, T.A.; Thompson, A.; Gandhi, K.K.; Hochberg, M.C.; Suissa, S. Incidence of malignancy in adult patients with rheumatoid arthritis: A meta-analysis. Arthritis Res. Ther. 2015, 17, 212. [CrossRef]

81. Hazlewood, G.S.; Barnabe, C.; Tomlinson, G.; Marshall, D.; Devoe, D.J.A.; Bombardier, C. Methotrexate monotherapy and methotrexate combination therapy with traditional and biologic disease modifying anti-rheumatic drugs for rheumatoid arthritis: A network meta-analysis. Cochrane Database Syst. Rev. 2016, 2016, 1-14. [CrossRef]

82. Song, J.W.; Lee, H.-K.; Lee, C.K.; Chae, E.J.; Jang, S.J.; Colby, T.V.; Kim, D.S. Clinical course and outcome of rheumatoid arthritis-related usual interstitial pneumonia. Sarcoidosis Vasc. Diffus. lung Dis. Off. J. WASOG 2013, 30, 103-112.

83. Wijsenbeek, M.; Kreuter, M.; Olson, A.; Fischer, A.; Bendstrup, E.; Wells, C.D.; Denton, C.P.; Mounir, B.; Zouad-Lejour, L.; Quaresma, M.; et al. Progressive fibrosing interstitial lung diseases: Current practice in diagnosis and management. Curr. Med. Res. Opin. 2019, 35, 2015-2024. [CrossRef]

84. Wijsenbeek, M.; Bendstrup, E.; Valenzuela, C.; Henry, M.T.; Moor, C.; Bengus, M.; Perjesi, A.; Gilberg, F.; Kirchgaessler, K.-U.; Vancheri, C. Design of a Study Assessing Disease Behaviour During the Peri-Diagnostic Period in Patients with Interstitial Lung Disease: The STARLINER Study. Adv. Ther. 2019, 36, 232-243. [CrossRef]

85. O’Dwyer, D.N.; Armstrong, M.E.; Cooke, G.; Dodd, J.D.; Veale, D.J.; Donnelly, S.C. Rheumatoid Arthritis (RA) associated interstitial lung disease (ILD). Eur. J. Intern. Med. 2013, 24, 597-603. [CrossRef]

86. Fischer, A.; Brown, K.K.; Du Bois, R.M.; Frankel, S.K.; Cosgrove, G.P.; Fernandez-Perez, E.R.; Huie, T.J.; Krishnamoorthy, M.; Meehan, R.T.; Olson, A.L.; et al. Mycophenolate mofetil improves lung function in connective tissue disease-associated interstitial lung disease. J. Rheumatol. 2013, 40, 640-646. [CrossRef]

87. Swigris, J.J.; Olson, A.L.; Fischer, A.; Lynch, D.A.; Cosgrove, G.P.; Frankel, S.K.; Meehan, R.T.; Brown, K.K. Mycophenolate mofetil is safe, well tolerated, and preserves lung function in patients with connective tissue disease-related interstitial lung disease. Chest 2006, 130, 30-36. [CrossRef]

88. Tzouvelekis, A.; Galanopoulos, N.; Bouros, E.; Kolios, G.; Zacharis, G.; Ntolios, P.; Koulelidis, A.; Oikonomou, A.; Bouros, D. Effect and safety of mycophenolate mofetil or sodium in systemic sclerosis-associated interstitial lung disease: A meta-analysis. Pulm. Med. 2012, 2012. [CrossRef]

89. Saketkoo, L.A.; Espinoza, L.R. Experience of mycophenolate mofetil in 10 patients with autoimmune-related interstitial lung disease demonstrates promising effects. Am. J. Med. Sci. 2009, 337, 329-335. [CrossRef]

90. Oldham, J.M.; Lee, C.; Valenzi, E.; Witt, L.J.; Adegunsoye, A.; Hsu, S.; Chen, L.; Montner, S.; Chung, J.H.; Noth, I.; et al. Azathioprine response in patients with fibrotic connective tissue disease-associated interstitial lung disease. Respir. Med. 2016, 121, 117-122. [CrossRef]

91. Rojas-Serrano, J.; González-Velásquez, E.; Mejía, M.; Sánchez-Rodríguez, A.; Carrillo, G. Interstitial lung disease related to rheumatoid arthritis: Evolution after treatment. Reumatol. Clin. 2012, 8, 68-71. [CrossRef]

92. Ota, M.; Iwasaki, Y.; Harada, H.; Sasaki, O.; Nagafuchi, Y.; Nakachi, S.; Sumitomo, S.; Shoda, H.; Tohma, S.; Fujio, K.; et al. Efficacy of intensive immunosuppression in exacerbated rheumatoid arthritis-associated interstitial lung disease. Mod. Rheumatol. 2017, 27, 22-28. [CrossRef]

93. Md Yusof, M.Y.; Kabia, A.; Darby, M.; Lettieri, G.; Beirne, P.; Vital, E.M.; Dass, S.; Emery, P. Effect of rituximab on the progression of rheumatoid arthritis-related interstitial lung disease: 10 years' experience at a single centre. Rheumatology 2017, 56, 1348-1357. [CrossRef] 
94. Matteson, E.L.; Bongartz, T.; Ryu, J.H.; Crowson, C.S.; Hartman, T.E.; Dellaripa, P.F. Open-Label, Pilot Study of the Safety and Clinical Effects of Rituximab in Patients with Rheumatoid Arthritis-Associated Interstitial Pneumonia. Open J. Rheumatol. Autoimmun. Dis. 2012, 2, 53-58. [CrossRef]

95. Keir, G.J.; Maher, T.M.; Ming, D.; Abdullah, R.; De Lauretis, A.; Wickremasinghe, M.; Nicholson, A.G.; Hansell, D.M.; Wells, A.U.; Renzoni, E.A. Rituximab in severe, treatment-refractory interstitial lung disease. Respirology 2014, 19, 353-359. [CrossRef]

96. Antoniou, K.M.; Mamoulaki, M.; Malagari, K.; Kritikos, H.D.; Bouros, D.; Siafakas, N.M.; Boumpas, D.T. Infliximab therapy in pulmonary fibrosis associated with collagen vascular disease. Clin. Exp. Rheumatol. 2007, 25, 23-28.

97. Akiyama, M.; Kaneko, Y.; Yamaoka, K.; Kondo, H.; Takeuchi, T. Association of disease activity with acute exacerbation of interstitial lung disease during tocilizumab treatment in patients with rheumatoid arthritis: A retrospective, case-control study. Rheumatol. Int. 2016, 36, 881-889. [CrossRef]

98. Dowman, L.M.; McDonald, C.F.; Hill, C.J.; Lee, A.L.; Barker, K.; Boote, C.; Glaspole, I.; Goh, N.S.L.; Southcott, A.M.; Burge, A.T.; et al. The evidence of benefits of exercise training in interstitial lung disease: A randomised controlled trial. Thorax 2017, 72, 610-619. [CrossRef]

99. Weill, D.; Benden, C.; Corris, P.A.; Dark, J.H.; Davis, R.D.; Keshavjee, S.; Lederer, D.J.; Mulligan, M.J.; Patterson, G.A.; Singer, L.G.; et al. A consensus document for the selection of lung transplant candidates: 2014-An update from the Pulmonary Transplantation Council of the International Society for Heart and Lung Transplantation. J. Heart Lung Transplant. 2015, 34, 1-15. [CrossRef]

100. Yazdani, A.; Singer, L.G.; Strand, V.; Gelber, A.C.; Williams, L.; Mittoo, S. Survival and quality of life in rheumatoid arthritis-associated interstitial lung disease after lung transplantation. J. Heart Lung Transplant. 2014, 33, 514-520. [CrossRef]

101. Courtwright, A.M.; El-Chemaly, S.; Dellaripa, P.F.; Goldberg, H.J. Survival and outcomes after lung transplantation for non-scleroderma connective tissue-related interstitial lung disease. J. Heart Lung Transplant. 2017, 36, 763-769. [CrossRef]

102. Flaherty, K.R.; Wells, A.U.; Cottin, V.; Devaraj, A.; Walsh, S.L.F.; Inoue, Y.; Richeldi, L.; Kolb, M.; Tetzlaff, K.; Stowasser, S.; et al. Nintedanib in Progressive Fibrosing Interstitial Lung Diseases. N. Engl. J. Med. 2019, 381, 1718-1727. [CrossRef]

103. Behr, J.; Neuser, P.; Prasse, A.; Kreuter, M.; Rabe, K.; Schade-Brittinger, C.; Wagner, J.; Günther, A. Exploring efficacy and safety of oral Pirfenidone for progressive, non-IPF lung fibrosis (RELIEF)-A randomized, double-blind, placebo-controlled, parallel group, multi-center, phase II trial. BMC Pulm. Med. 2017, 17, 122. [CrossRef]

104. Phase 11 Study of Pirfenidone in Patients with RAILD (TRAIL1)—ClinicalTrials.Gov Study ID NCT02808871. Available online: https://clinicaltrials.gov/ct2/show/NCT02808871 (accessed on 15 August 2019).

105. Lacaille, D.; Avina-Zubieta, J.A.; Sayre, E.C.; Abrahamowicz, M. Improvement in 5-year mortality in incident rheumatoid arthritis compared with the general population-closing the mortality gap. Ann. Rheum. Dis. 2017, 76, 1057-1063. [CrossRef]

106. Koduri, G.; Norton, S.; Young, A.; Cox, N.; Davies, P.; Devlin, J.; Dixey, J.; Gough, A.; Prouse, P.; Winfield, J.; et al. Interstitial lung disease has a poor prognosis in rheumatoid arthritis: Results from an inception cohort. Rheumatology 2010, 49, 1483-1489. [CrossRef]

107. Solomon, J.J.; Chung, J.H.; Cosgrove, G.P.; Demoruelle, M.K.; Fernandez-Perez, E.R.; Fischer, A.; Frankel, S.K.; Hobbs, S.B.; Huie, T.J.; Ketzer, J.; et al. Predictors of mortality in rheumatoid arthritis-associated interstitial lung disease. Eur. Respir. J. 2016, 47, 588-596. [CrossRef]

108. Solomon, J.J.; Ryu, J.H.; Tazelaar, H.D.; Myers, J.L.; Tuder, R.; Cool, C.D.; Curran-Everett, D.; Fischer, A.; Swigris, J.J.; Brown, K.K. Fibrosing interstitial pneumonia predicts survival in patients with rheumatoid arthritis-associated interstitial lung disease (RA-ILD). Respir. Med. 2013, 107, 1247-1252. [CrossRef]

109. Nurmi, H.M.; Purokivi, M.K.; Kärkkäinen, M.S.; Kettunen, H.P.; Selander, T.A.; Kaarteenaho, R.L. Variable course of disease of rheumatoid arthritis-associated usual interstitial pneumonia compared to other subtypes. BMC Pulm. Med. 2016, 16, 107. [CrossRef]

110. Nurmi, H.M.; Purokivi, M.K.; Kärkkäinen, M.S.; Kettunen, H.-P.; Selander, T.A.; Kaarteenaho, R.L. Are risk predicting models useful for estimating survival of patients with rheumatoid arthritis-associated interstitial lung disease? BMC Pulm. Med. 2017, 17, 16. [CrossRef] 
111. Sparks, J.A.; He, X.; Huang, J.; Fletcher, E.A.; Zaccardelli, A.; Friedlander, H.M.; Gill, R.R.; Hatabu, H.; Nishino, M.; Murphy, D.J.; et al. Rheumatoid arthritis disease activity predicting incident clinically-apparent RA-associated interstitial lung disease: A prospective cohort study. Arthritis Rheumatol. 2019. [CrossRef]

112. Jacob, J.; Hirani, N.; Van Moorsel, C.H.M.; Rajagopalan, S.; Murchison, J.T.; Van Es, H.W.; Bartholmai, B.J.; Van Beek, F.T.; Struik, M.H.L.; Stewart, G.A.; et al. Predicting outcomes in rheumatoid arthritis related interstitial lung disease. Eur. Respir. J. 2019, 53. [CrossRef] [PubMed]

113. Goh, N.S.L.; Desai, S.R.; Veeraraghavan, S.; Hansell, D.M.; Copley, S.J.; Maher, T.M.; Corte, T.J.; Sander, C.R.; Ratoff, J.; Devaraj, A.; et al. Interstitial lung disease in systemic sclerosis: A simple staging system. Am. J. Respir. Crit. Care Med. 2008, 177, 1248-1254. [CrossRef] [PubMed]

(C) 2019 by the authors. Licensee MDPI, Basel, Switzerland. This article is an open access article distributed under the terms and conditions of the Creative Commons Attribution (CC BY) license (http://creativecommons.org/licenses/by/4.0/). 